\title{
Behavioral observations of an upcurrent reef colonization event by larval surgeonfish Ctenochaetus strigosus (Acanthuridae)
}

\author{
Gorka Sancho*, Diana Ma**, Phillip S. Lobel** \\ Department of Biology, Woods Hole Oceanographic Institution, Woods Hole, Massachusetts 02543, USA
}

\begin{abstract}
Two reef colonization events by larval acanthurids were observed at Johnston Atoll, Central Pacific. In one event, pelagic larvae of Ctenochaetus strigosus were observed swimming in groups along the bottom of a reef channel and actively settling to caves and crevices. These larvae were swimming against a current that averaged $27 \mathrm{~cm} \mathrm{~s}^{-1}$ at a height of $1.5 \mathrm{~m}$ above the substrate. This observation confirms the importance of larval swimming abilities during colonization of some reef fishes and indicates a potential undersampling of larvae by passive plankton nets. Predation occurred on these incoming larvae by 8 piscivorous species, while no predation was observed during the second colonization event.

KEY WORDS: Coral reef Colonization Recruitment Reef fish larvae - Swimming behavior Ctenochaetus strigosus
\end{abstract}

\section{INTRODUCTION}

Most coral reef fishes have a life history which includes a pelagic larval stage. The movement of competent larvae from the pelagic environment to the reef environment is referred to as 'colonization' (Dufour \& Galzin 1993). Once fish are situated over the reef, 'settlement' of the larvae onto the reef can take place or not. Settlement patterns influence the population dynamics of coral reef fishes (Victor 1983, Doherty \& Williams 1988, Jones 1990, Robertson 1992). Recent studies of temperate fishes indicate the importance of presettlement larval behavior in the proximity of the reef in determining the actual settlement of larvae onto the benthic environment (Breitburg 1991, Breitburg et al. 1995). The defined patterns of larval supply (Dufour 1991, Dufour \& Galzin 1993) combined with measurements of larval swimming abilities (Stobutzki \& Bell-

\footnotetext{
- E-mail: gsancho@whor.edu

- Present address: Boston University Marine Program, Woods Hole, Massachusetts 02543, USA
}

wood 1994) support the notion that larval behavior during the transitional period of colonization is important in determining the settlement patterns of tropical reef fishes (Kaufman et al. 1992)

Many studies regarding the supply of larvae to the reefs have relied on censuses of recently recruited juvenile fishes on the reef, as well as on the measurement of daily otolith increments to estimate time of settlement. These are indirect methods that can be confounded by mortality of settlers (Doherty \& Sale 1985 , Hixon 1991, Connell 1996) and specific habitat selection (Sweatman 1985, Booth 1992). Planktonic larvae have been sampled with a variety of towed nets, but net avoidance by large larvae has always hindered the results concerning late-stage presettlement fishes (Choat et al. 1993). Light aggregating devices (nightlights and light-traps) have also been used to sample late-stage larval fishes in the proximity of reefs (Victor 1983, Doherty 1987), but these methods are selective for certain taxa (Thorrold 1992, Choat et al. 1993). Recently developed techniques now allow one to sample presettlement larvae during the actual transition period of reef colonization. Crest nets (Dufour 1991, 
Dufour et al. 1996) measure the supply of larvae over the reef crest while channel nets (Shenker et al. 1993, Thorrold et al. $1994 \mathrm{a}, \mathrm{b}, \mathrm{c})$ measure the supply of larvae through channels across the reef. Both methods are based on passive nets that intercept larval fishes as they enter the reef with the currents. Passive nets only sample larvae incoming with the current. Any larval movement toward a reef in a direction opposite to the currents would not be detected by either method.

Mortality of newly settled recruits is very high (Doherty \& Sale 1985, Victor 1986, Shulman \& Ogden 1987). Predation is considered to be an important factor in reducing survivorship and ultimately influencing reef fish populations (review by Hixon 1991). Dufour \& Galzin (1992) indicated the great differences between abundance of presettlement colonizing larvae at the reef crest and settled individuals in the reef, indicating high mortality of larvae during the colonization of the reef, which was attributed to predation by resident small piscivorous fish.

This study presents the direct observation of a colonizing event by Ctenochaetus strigosus (Acanthuridae) larya and describes the behavior of these pelagic larvae while encountering a reef. The observed larval behaviors in relation with the water flow have important implications for the interpretation of data on colonization obtained with passive collection methods.

\section{METHODS}

Johnston Atoll is in the Central Pacific $\left(16^{\circ} 45^{\prime} \mathrm{N}\right.$, $169^{\circ} 30^{\prime} \mathrm{W}$, $760 \mathrm{~km}$ south from French Frigate Shoal, one of the northwestern Hawailan islands which is the closest shallow reef system. The atoll has a maximum width of $20 \mathrm{~km}$ and a reef crest only along its N-NW edge (Fig. 1). Tide amplitude ranges about $1 \mathrm{~m}$.

A colonization event by Ctenochaetus strigosus larvae (Observation 1) was observed and videotaped by 2 of the authors (G.S. and D.M.) while SCUBA diving at a channel that transects the reef crest (Fig. 1). The channel is on average $4.5 \mathrm{~m}$ deep and $28 \mathrm{~m}$ wide, and has a substrate composed of broken coral rubble and patches of live coral (Acropora spp. and other species) Two current meters (S4 InterOcean, San Diego) were in place at the time of this observation. The first one was located in the channel and mounted on a tripod at a height of $1.5 \mathrm{~m}$ above the substrate. The second unit was moored of fshore $200 \mathrm{~m}$ from the reef crest, directly in front of the channel at a depth of $13 \mathrm{~m}$ (10 m off the bottom). Two temperature loggers (XL-100 Braencker Research. Toronto) were deployed with the current meters. Direct observations of incoming larvae were made at this site from 19:00 until 20:00 h (sunset at 19:41 h) on May 12, 1994, a day after new moon. Set-

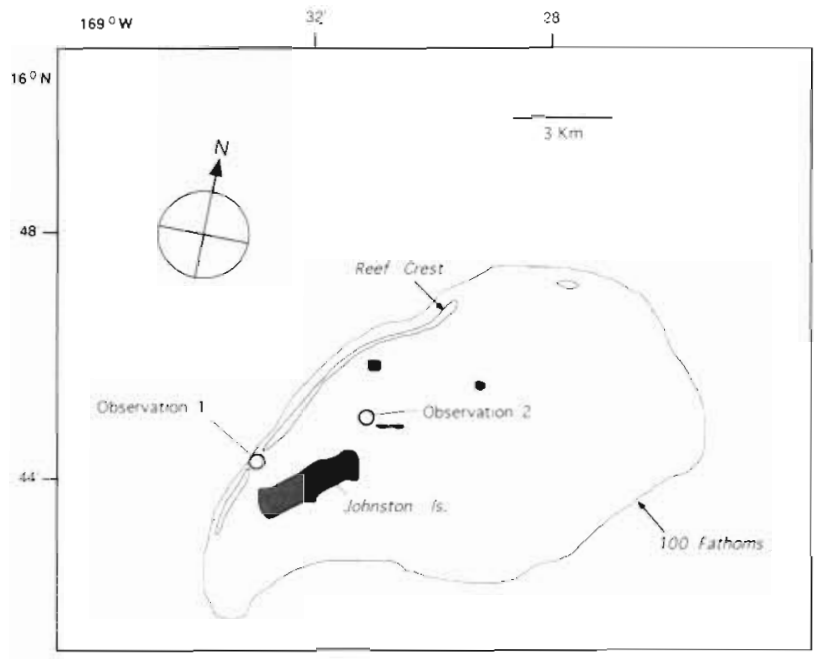

Fig. 1 Map of Johnston Atoll indicating the location of the reef channel where observations were made in 1994 (Observation 1) and the location of the 1995 observation inside the lagoon (Observation 2)

thed individuals were collected from the reef the next day $(10.00 \mathrm{~h})$ for identification purposes using quinaldine and hand nets.

A second event of colonizing acanthurid larvae (Observation 2) was observed and videotaped by 1 of the authors (P.S.L.) on May 1, 1995, from 14:00 until 16:00 $\mathrm{h}$ approximately. Observation 2 took place inside the lagoon (Fig. 1), close to a deep (10 m) channel and over a bottom of industrial debris and coral heads. The depths at this location ranged from 5 to $8 \mathrm{~m}$.

\section{RESULTS}

\section{Currents}

Currents in both the reef channel and offshore from the reef crest were tidally influenced. The water flow in the channel at the time of the larval observations was oriented in an outward direction, with an average speed of $27 \mathrm{~cm} \mathrm{~s}^{-1}$ at $1.5 \mathrm{~m}$ off the bottom (Fig. 2). Using the logarithmic law for velocity distributions in turbulent flows (Schlichting 1979), we estimated the water velocity at different heights off the bottom. Considering a substrate composed of coral gravel of 2 to $5 \mathrm{~cm}$ in diameter, the current speed 2 to $5 \mathrm{~cm}$ above the bottom should vary between 10 and $15 \mathrm{~cm} \mathrm{~s}^{-1}$

The currents in the offshore station ran parallel to the reef and, at the observation time, were flowing towards the NE at an average speed of $14 \mathrm{~cm} \mathrm{~s}^{-1}$ (Fig 2). A sharp rise in temperature $\left(0.25^{\circ} \mathrm{C}\right.$ ) at the offshore station coincided in time with the colonization event. 

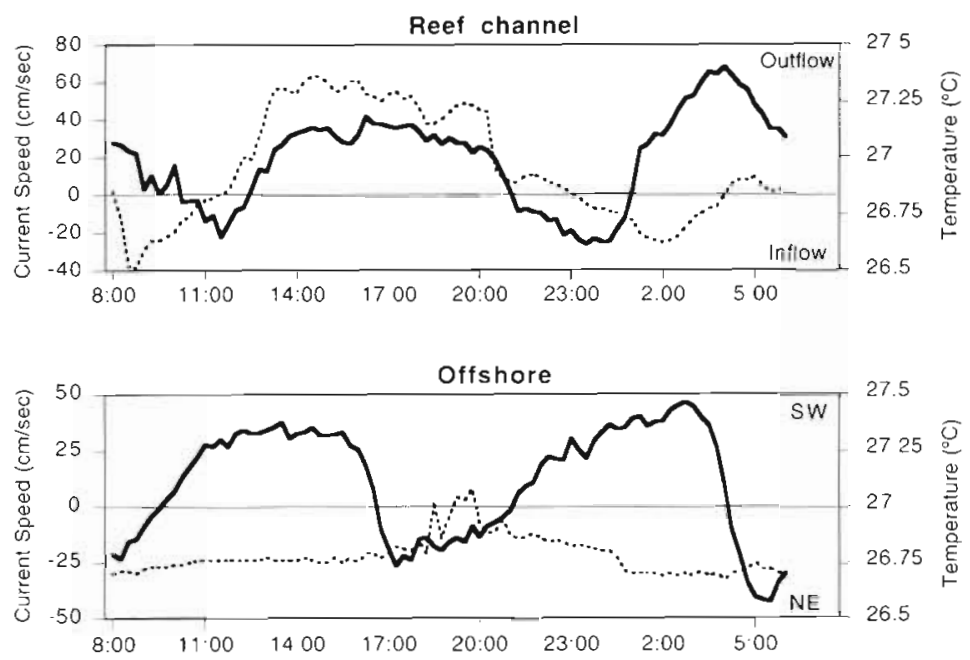

Fig. 2. Water flow and temperature measurements on May 12, 1994. Solid lines represent water flow velocity, dotted lines represent water temperature. Grey areas indicate the time when observations of larvae were made (Observation 1). On the reef channel $(1.5 \mathrm{~m}$ off the bottom) positive flow velocity values indicate outflowing direction (exiting the lagoon) and negative values represent inflowing direction (into the lagoon). At the offshore site $(10 \mathrm{~m}$ off the bottom) positive flow velocity values indicate alongshore southwest direction and negative values indicate alongshore nor theast direction

\section{Larval behavior}

During Observation 1, large numbers (hundreds) of Ctenochaetus strigosus larvae were observed to be actively swimming along the substrate. The colonizing fish were typical pelagic unmetamorphosed larvae, with transparent bodies and little pigmentation. The average standard length of 10 randomly collected specimens was $2.8 \mathrm{~cm}(\mathrm{SD}=0.1)$.

Two distinct larval behaviors were observed at the channel: (1) Fish would hide along the substrate, occupying small holes, and underneath rocks. These 'settled' fish aggressively defended their positions from new incoming larvae. (2) The majority of larvae were observed to be actively swimming in tight schools that varied in size from 5 to approximately 25 individuals. Almost no fish were observed swimming alone. Their swimming was very directional, always moving from the outside of the reef towards the lagoon. All fish were swimming a few centimeters off the bottom along the channel, no larvae were observed swimming in midwater or at the surface. Larvae appeared to use the topographic obstacles to help in their advance against the current, resting momentarily behind boulders before continuing their advance. Many sought refuge in the irregularities of the substrate, mostly underneath flat broken pieces of Acropora. If these corals were already occupied, resident larvae would attack the new incoming fish. On most occasions the rejected fish would resume swimming along the bottom towards the lagoon. We observed several groups of larvae traveling 30 to $40 \mathrm{~m}$ up-current without taking refuge in the reef.

This was the only direct observation of a larval colonization event at this site after $191 \mathrm{~h}$ of behavioral observations by 1 of the authors (G.S.), 30 of which were done at dusk. All observations were done during the peak reproductive season of Ctenochaetus strigosus at Johnston Atoll (Sancho pers. obs.) and Hawaii (Lobel 1989).

Observation 2 took place in daytime (14:00 to $16: 00 \mathrm{~h}$ ) during a flood tide. Tight groups of surgeonfish larvae, varying in number from 30-40 individuals up to a few thousand, were observed advancing at heights of 0.5 to $2 \mathrm{~m}$ above the substrate following the contour. These large schools were composed mostly of dark pigmented presettlement surgeonfish larvae of various sizes, with a few partially transparent individuals mixed in the schools. Currents were not measured directly, but the highly directional swimming of the larvae appeared to be oriented in the same direction as the weak existing current, flowing in from a deep shipping channel on the south side of the Atoll.

\section{Predation}

Predatory fish of various families were very active at the reef channel during Observation 1, attacking groups of larvae as they progressed along the bottom. Five species were observed to successfully attack and ingest larvae during the colonization event. Individuals of Caranx melampygus (Carangidae) of small and medium size (20 to $40 \mathrm{~cm}$ approximately) patrolled the bottom of the channel at very high speeds and rushed violently against moving groups of larvae, grabbing coral rubble in the process which was quickly ejected. Large Parupeneus cyclostomus (Mullidae) were observed swimming very agitatedly around broken flat pieces of coral, using their barbels to search underneath them and moving adjacent gravel in search of hiding larvae. One male (33 cm standard length) was collected by spear and its stomach contained 5 undigested acanthurid larvae. Individual Cirrhitus pinnulatus (Cirrhitidae) were observed stalking and attacking passing groups of larvae while perched on the edge of large coral heads. One individual $(21 \mathrm{~cm}$ standard length) was collected by spear and its stomach contained 2 undigested Ctenochaetus strigosus larvae. Four Fistularia commersonii (Fistulariidae) were ob- 
served over the coral rubble maintaining their position against the current about 10 to $20 \mathrm{~cm}$ above the substrate. They struck individual larvae swimming past them along their side or underneath them. Finally, 1 individual Aulostomus chinensis (Aulostomidae) was observed striking once at a swimming acanthurid larvae. No predatory events by any of the above piscivores have ever been observed at this site during the dusk period on other dates.

No wrasses (Labridae) were observed to attack larvae at dusk, but during the following morning $(10: 00 \mathrm{~h})$, while collecting settled larvae, we observed various successful attacks by Epibulus insidiator on undisturbed individual larvae which were poking from underneath corals. Thalassoma duperrey, T. lutescens and Coris gaimard actively followed divers and preyed upon larvae that were evacuated from their refuges by divers while collecting. These were the only successful predation events observed in the morning hour, none of the predatory species observed during the dusk period were active during the morning.

No attacks on swimming larvae by piscivorous fish where observed during the second colonization cvent inside the lagoon.

\section{DISCUSSION}

Our observation of Ctenochaetus strigosus larvae swimming through a reef channel against the water flow to the inner reef environment suggests that the colonization of coral reefs by presettlement pelagic larvae can be an active process, controlled by behavioral responses of the larvae. Larval movement is not constrained to transport by currents, specially for large larvae with strong swimming abilities such as Acanthuridae, which have been measured swimming at speeds of $13.5 \mathrm{~cm} \mathrm{~s}^{-1}$ and for distances equivalent to $90 \mathrm{~km}$ in an experimental apparatus (Stobutzki \& Bellwood 1997). We observed directly surgeonfish larvae advancing against an estimated current of 10 to $15 \mathrm{~cm} \mathrm{~s}^{-1}$

Our observation of tightly aggregated groups of surgeonfish larvae swimming upstream along the substrate using topographical features to avoid high flows and predators is analogous to the behaviors displayed by temperate larval gobiids on oyster beds (Breitburg 1991, Breitburg et al. 1995). Presettlement demersal shoaling behaviors have been observed in the field for various families of temperate (Marliave 1986, Breitburg 1991) and tropical (Kaufman et al. 1992) reef fishes, which have also been observed to school while in the neuston (McCormick \& Milicich 1993). Future observational efforts to detect demersal shoaling behaviors in tropical reefs should focus on the dusk period, since it is used by many species as a colonization time (Dufour 1991, Dufour \& Galzin 1993) and light levels are sufficient for visual observations.

The use of channel nets (Shenker et al. 1993, Thorrold et al. 1994a, b, c) and crest nets (Dufour 1991, 1994, Dufour \& Galzin 1992, 1993, Doherty \& McIlwain 1996, Dufour et al. 1996) has recently facilitated the direct sampling of colonizing larvae as they enter the reef system. Channel nets sample only larvae that are transported by the currents or are actively swimming in the same direction as the water flow. The colonization event through the reef channel described in this paper (Observation 1) would have been undetected by channel nets since the larvae were swimming against the current while advancing through the channel. Crest nets sample the whole water column and depend on the currents and turbulence created by breaking waves over the reef crest to capture larvae. Colonizing larvae swimming against an outílowing current along the reef crest substrate might detect and avoid a crest net encountered in their way, resulting in an undersampling of incoming larvae. It is unknown how widesprcad this kind of swimming behavior is in reef fish larvae, but it points towards a potential source of error when estimating larval supply with sampling methods based on current transport. The degree of underestimation of larval flux will vary with sampling gear used, the flow characteristics of different reef systems, and with differences in swimming behavior and abilities of different taxa.

Predation has been considered the principal cause for the high mortality rates of juvenile fishes (Victor 1986, Shulman \& Ogden 1987, Hixon 1991). Dufour \& Galzin (1992) discovered large differences in abundance between the flux of larvae over the reef crest and the number of resident fish detected afterwards in the lagoon. The differences were attributed to predation of colonizing larvae by resident piscivorous fishes. Our observations of 5 species of small piscivores successfully consuming colonizing surgeonfish larvae along the reef channel supports the potential importance of predation during the transitional period of reef colonization.

In comparison, during Observation 2 no signs of predation were detected. It is unknown if the absence of predation events observed during this second event was due to the abnormal time of colonization, a lower abundance of predators at the observation site or to previous satiation of predators due to the large number of incoming larvae. But this lack of daytime predation. brings up the question of whether the usual time of larval colonization during low light levels (dusk and nights) is to avoid predation or due to other causes.

In conclusion, our observation of presettlement surgeonfish larvae swimming along the reef in shoals 
against a current demonstrates the capabilities of tropical reef fishes to gain access to the reef against the water flow. This behavior should be considered in the design of future studies of reef colonization events, specially when sampling strong swimming larvae with passive nets in locations with variable currents. It should also be taken into account when estimating absolute rates of larval flux (Doherty \& McIlwain 1996. Dufour et al. 1996) over reefs where offshore currents exist. Larval colonization may be higher than estimates based on passive net sampling techniques. More work describing and quantifying the behavior of the colonizing larvae is needed to address these questions.

Acknowledgements. We thank Lauren Mullineaux, Vincent Dufour and 4 anonymous reviewers for invaluable comments on earlier versions of the paper. $V$ Dufour graciously identified the larvae from the first colonization event. The work was supported by grants to P.S.L. from the U.S. Army Chemical Material Destruction Agency (via NOAA Sea Grant NA90AA-D-SG535 and the Office of Naval Research N00014-91J1591 and N00014-92-J-1969) and the U.S. Army Legacy Resource Management Program (DAMD 17-93-J-3052). G.S. was also supported by a 'La Caixa' fellowship. Contribution 9471 of the Woods Hole Oceanographic Institution

\section{LITERATURE CITED}

Booth DJ (1992) Larval settlement patterns and preferences by domıno damselfish Dascyllus albisella Gill. J Exp Mar Biol Ecol 155:85-104

Breitburg DL (1991) Settlement patterns and presettlement behavior of the naked goby, Gobiosoma bosci, a temperate oyster reef fish. Mar Biol 109:213-221

Breitburg DL, Palmer MA, Loher T (1995) Larval distributions and the spatial patterns of settlement of an oyster reef fish: responses to flow and structure. Mar Ecol Prog Ser 125. $45-60$

Choat JH, Doherty PJ, Kerrigan BA, Leis JM (1993) A comparison of towed nets purse seine and light-aggregation devices for sampling larvae and pelagic juveniles of coral reef fishes. Fish Bull 91:195-209

Connell SD (1996) Variations in mortality of a coral-reef fush: links with predator abundance. Mar Biol 126:347-352

Doherty PJ (1987) Light-traps: selective but useful devices for quantifying the distributions and abundances of larval fishes. Bull Mar Sci 41:423-431

Doherty PJ, MCllwain J (1996) Monitoring larval fluxes through the surf zones of Australian coral reefs. Mar Freshwat Res 47:83-90

Doherty PJ, Sale PF (1985) Predation on juvenile coral reef fishes: an exclusion experiment. Coral Reefs 4:225-234

Doherty PJ, Williams DM (1988) The replenishment of coral reef fish populations. Oceanogr Mar Biol Annu Rev 26:487-551

Dufour V (1991) Variations d'abondance des larves de poissons en milieu récifal: effet de la muniere sur la colonisation larvaire. CR Acad Sci Paris 313:187-194

Dufour $V(1994)$ Colonization of fish larvae in lagoons of Rangrroa (Tuamotu Archipelago) and Moorea (Society Archipelago). Atoll Res Bull 416

Dufour V, Galzin R (1992) Le recruitment des poissons récjfaux sur l'ile de Moorea, Polynésie française. Impact sur la dynamique des populations et conséquences sur la gestion des stocks. Cybium 16:267-277

Dufour V, Galzin R (1993) Colonization patterns of reef fish larvae to the lagoon at Moorea Island, French Polynesia. Mar Ecol Prog Ser 102:143-152

Dufour V, Riclet E, Lo-Yat A (1996) Colonization of reef fishes at Moorea Island French Polynesia: temporal and spatial variation of the larval flux. Mar Freshwater Res 47. $413-422$

Hixon MA (1991) Predation as a process structuring coral reef communities. In: Sale PF (ed) The ecology of fishes on coral reefs. Academic Press, San Diego, p 475-508

Jones GP (1990) The importance of recruitment to the dynamics of a coral reef population. Ecology 71:1691-1698

Kaufman L, Ebersole J, Beets J, McIvor CC (1992) A key phase in the recruitment dynamics of coral reef fishes: post-settlement transition. Environ Biol Fish 34:109-118

Lobel PS (1989) Ocean variability and the spawning season of Hawaiian reef fishes. Environ Biol Fish 24:161-171

Marliave JB (1986) Lack of planktonic dispersal of rocky intertidal fish larvae. Trans Am Fish Soc 115:149-154

McCormick MI, Milicich MJ (1993) Late pelagic-stage goatfishes: distribution patterns and inferences on schooling behavior. J Exp Mar Biol Ecol 174:15-42

Robertson DR (1992) Patterns of lunar settlement and early recruiment in Caribbean reef fishes at Panama. Mar Biol $114: 527-537$

Schlichting H (1979) Boundary-layer theory. McGraw-Hill, New York

Shenker JM, Maddox ED. Wishinski E, Pearl A, Thorrold SR, Smith $N$ (1993) Onshore transport of settlement-stage Nassau grouper Epinephelus striatus and other fishes in Exuma Sound, Bahamas. Mar Ecol Prog Ser 98:31-43

Shulman MJ, Ogden JC (1987) What controls tropical reef fish populations: recruitment or benthıc mortality? An example in the Caribbean reef fish Haemuleon flavolineatum. Mar Ecol Prog Ser 39:233-242

Stobutzki IC, Bellwood DR (1994) An analysis of the sustained swimming abilities of pre-and post-settlement coral reef fishes. J Exp Mar Biol Ecol 175:275-286

Stobutzki IC, Bellwood DR (1997) Sustained swimming abilities of the late pelagic stages of coral reef fishes. Mar Ecol Prog Ser 149:35-41

Sweatman HPA. (1985) The influence of adults of some coral reef fishes on larval recruitment. Ecol Monogr 55:469-485

Thorrold SR (1992) Evaluating the performance of light traps for sampling small fish and squid in open waters of the Great Barrier Reef lagoon. Mar Ecol Prog Ser 89. $277-285$

Thorrold SR, Shenker JM, Maddox ED, Mojica R, Wishinski E (1994a) Larval supply of shorefish to nursery habitats around Lee Stocking Island, Bahamas. II. Lunar and oceanographical influences. Mar Biol 118:567-578

Thorrold SR, Shenker JM, Mojica R, Maddox ED, Wishinski E (1994b) Temporal patterns in the larval supply of summerrerruiting reef fish to Lee Stocking Island, Bahamas. Mar Licol Prog Sor 112:75-86

Thorrold SR, Shenker JM, Wishinski E, Mojica R, Maddox ED (1994c) Larval supply of shorefish to nursery habitats around Lee Stocking Island, Bahamas. I. Small-scale distribution patterns. Mar Biol 118:555-566

Victor BC: (1983) Recruitment and population dynamics of a coral reef fish. Science 219:419-420

Victor BC (1986) Larval settlement and juvenile mortality in a recruitment-limited coral reef fish population. Ecol Monogr 56:145-160

Manuscript first received: March 3, 1997

Revised version accepted: May 26, 1997 